\title{
PENGGUNAAN PERMAINAN KARAMBOL UNTUK MENINGKATKAN HASIL BELAJAR BERHITUNG PADA ANAK TUNAGRAHITA SEDANG
}

\author{
EVI SUSILAWATI \\ SPLB C YPLB Kota Bandung \\ susilawatievi1903@email.ac.id
}

\begin{abstract}
ABSTRAK
Tujuan yang hendak dicapai dalam penelitian tindakan kelas ini adalah: 1. Untuk mengetahui ada tidaknya penggunaan media permaianan karambol dalam meningkatkan hasil belajar bagi anak tunagrahita sedang. 2. Untuk mengetahui berpengaruh atau tidaknya penggunaan media permainan karambol untuk kelancaran proses belajar berhitung bagi anak tunagrahita sedang. 3. Untuk mengetahui dapat tidaknya media permainan karambol menumbuhkan perhatian, minat dan rasa senang bagi anak tunagrahita sedang dalam proses pembelajaran berhitung. Penelitian ini merupakan penelitian tindakan kelas yang diadaptasi dari model kemmis dan Mc.Taggart. Oleh karena itu penelitian ini dilakukan dalam beberapa tahapan. Setiap tahapan terdiri dari perencanaan, pelaksanaan,observasi dan refleksi. Kemampuan siswa tunagrahita sedang mengalami peningkatan setelah mendapatkan pembelajaran dengan menggunakan media permainan karambol. Hal ini terlihat dari peningkatan hasil belajar siswa pada setiap siklusnya. Pada siklus pertama rata-rata kenaikan hasil belajar 1\% siklus kedua ada peningkatan $0,5 \%$ dan siklus ketiga ada peningkatan hasil belajar 0,75\%. Kesimpulan dari penelitian tindakan kelas ini yaitu perencanaan pembelajaran berhitung dilakukan dengan tiga siklus. Perencanaan pembelajaran diawali dengan membuat RPP, instrumen penilaian dan instrumen pengamatan. Pelaksanaan pembelajaran berhitung meletakkan benda sesuia dengan lambang bilangannya dengan menggunakan media permainan karambol secara umum berjalan dengan lancar. Kemampuan berhitung siswa kelas VI tunagrahita sedang mengalami peningkatan hasil belajar setelah mendapatkan pembelajaran dengan menggunakan media permainan karambol. Berdasarkan temuan tersebut, dapat disarankan bahwa media permainan karambol dapat dijadikan medai alternatif dalam upaya meningkatkan hasil belajar berhitung meletakkan benda sesuai dengan lambang bilangannya.
\end{abstract}

Kata Kunci : Tunagrahita Sedang, Berhitung, Permainan Karambol

ABSTRACT
The objectives to be achieved in this classroom action research are: 1 . To determine whether or not the use of carom game media in improving learning outcomes for children with moderate mental retardation. 2. To find out whether or not the use of carom game media is effective for the smooth learning process of counting for children with moderate mental retardation. 3 . To find out whether the carom game media can foster attention, interest and pleasure for mentally retarded children who are in the process of learning to count. This research is a classroom action research adapted from the model of Kemmis and Mc.Taggart. Therefore, this research was conducted in several stages. Each stage consists of planning, implementation, observation and reflection. The ability of mentally retarded students is increasing after getting learning using carrom game media. This can be seen from the increase in student learning outcomes in each cycle. In the first cycle the average increase in learning outcomes is $1 \%$, the second cycle there is an increase of $0.5 \%$ and the third cycle there is an increase in learning outcomes of $0.75 \%$. The conclusion of this classroom action research is that the planning of numeracy learning is carried out in three cycles. Learning planning begins with making lesson plans, assessment instruments and observation instruments. The implementation of learning to count puts objects in accordance with the number symbol by using carrom game media in general runs smoothly. The numeracy ability of the mentally retarded class VI students is experiencing an increase in learning outcomes after receiving learning using carom game media. Based on these findings, 
it can be suggested that the carom game media can be used as an alternative medium in an effort to improve the learning outcomes of counting placing objects according to the number symbol. Keywords : Moderate Mental retardation, Counting, Carrom Game

\section{PENDAHULUAN}

Pendidikan dilakukan secara teratur dan sistematis dalam upaya untuk mendewasakan anak didik, baik dari segi pengetahuan, kemampuan maupun sikap, tidak hanya diperuntukkan bagi mereka yang normal saja, tetapi juga bagi mereka yang mengalami kelainan berhak dan memerlukan layanan .Pendidikan akademik bagi anak tunagrahita merupakan hal yang sangat penting untuk mendukung tujuan utama pendidikan yaitu menuju kehidupan sehari-hari. Dalam pengajaran di ruang lingkup anak tunagrahita, prestasi tidak dijadikan tujuan utama dari pelajaran yang diberikan karena memang pada kenyataannya sulit untuk mengharapkan mereka dapat berprestasi minimal mendekati kemampuan berprestasi anak normal lainnya. Pengajaran pada anak tunagrahita mempunyai tujuan utama untuk membantu mereka dalam kehidupan sehari-hari, agar mereka dapat lebih mandiri, tidak mudah untuk ditipu, dapat mengoptimalkan kemampuannya untuk dipergunakan dalam kehidupan sehari-hari di kehidupan bermasyarakat.

Kesulitan yang timbul di dalam proses pengajaran adalah kecenderungan yang ditemui pada anak tungrahita sangat beraneka ragam bahkan dalam satu kelas dapat ditemui beberapa pola tingkah laku yang berbeda antara satu anak dengan anak yang lainnya. Hal ini menyebabkan seorang guru dalam menyampaikan materi pelajaran tidak dapat disampaikan secara optimal karena setiap individu memerlukan waktu yang cukup lama dalam memberikan materi pelajaran kepada masing-masing anak tunagrahita.

Banyak diantara siswa tunagrahita sedang walaupun telah duduk di kelas 6 SDLB-C1 tetapi belum dapat berhitung, menulis dan membaca tetapi mereka dapat naik kelas karena persyaratan naik kelas tidak didasari oleh hasil nilai yang bagus tetapi didasarkan oleh umur. Apabila umur anak yang bersangkutan telah mencukupi untuk naik kelas maka serendah apapun kemampuan yang anak miliki dia tetap naik kelas dan berdasarkan pengalaman di lapangan anak tunagrahita sedang disaat mereka jajan membeli kue seharga dua ribu seharusnya dapat tiga kue tetapi hanya dikasih dua kue. Berdasarkan hal tersebut anak kurang mengetahui berapa jumlah benda yang harus ada dengan angka dengan kata lain anak masih kurang mengetahui cara meletakkan benda sesuai dengan lambang bilangannya . Karena itu diperlukan media untuk membantu proses pengajaran agar materi pelajaran dapat disampaikan secara optimal dan membantu pengajar dalam memberikan materi pelajaran yang berbeda-beda diantara kecenderung para siswa yang beraneka ragam antara yang satu dengan yang lainnya. Sehingga pengajar tidak harus selalu melakukan pengajaran bersifat individual yang memerlukan waktu cukup lama sehingga banyak materi pelajaran yang lainnya tidak didapat oleh siswa secara maksimal.

Berbagai permasalahan yang cukup kompleks dihadapi anak tunagrahita dalam proses pembelajaran di dalam kelas, semua itu terkait dengan keterbatasan kemampuan intelektual yang dimiliki oleh anak tunagrahita sedang. (Sutjihati dalam Astati, 2006) menyatakan tunagrahita adalah kelainan yang ditandai dengan adanya keterbatasan yang signifikan dalam aspek fungsi intelektual dan prilaku adaptif yang diekspresikan dalam bentuk konseptual, sosial dan keterampilan adaptif. Hal pokok dalam proses pembelajaran yang semestinya diberikan dan dikuasai oleh siswa secara umum adalah tentang kemampuan membaca, menulis dan berhitung selain keterampilan-keterampilan lainnya. Berkaitan dengan keterbatasan yang dimiliki oleh anak tunagrahita apalagi anak tunagrahita sedang maka untuk mencapai suatu keberhasilan secara nyata dalam proses pembelajaran diperlukan langkah-langkah, metode serta alat peraga yang sekiranya dapat membantu memenuhi proses pembelajaran yang aktif, kreatif dan menyenangkan. Proses belajar mengajar pada hakekatnya merupakan suatu proses interaksi antara siswa dan guru yang disertai dengan penggunaan media tertentu, sehinga tujuan yang diinginkan dapat tercapai. seperti yang dikemukakan (Oemar Hamalik,1994) Media pendidikan adalah alat, metode dan teknik yang digunakan dalam rangka untk lebih 
mengefektifkan komunikasi dan interaksi antara guru dan siswa dalam proses pendidikan dan pengajaran di sekolah Suatu hal yang sudah tentu dihadapi oleh anak tuna grahita sedang dalam proses pembelajaran adalah siswa tunagrahita sedang cepat merasa bosan, tidak tahan lama dalam belajar, cepat lupa, kurang motivasi belajarnya dan sulit untuk menguasai suatu materi pelajaran. Untuk menghadapi permasalahan tersebut maka seorang guru dituntut untuk memberikan pembelajaran yang kreatif, memiliki kepekaan terhadap permasalahan yang ditemui dan mencari berbagai solusi agar pembelajaran berlangsung secara efektif dan efesien, agar keberhasilan yang diharapkan dapat tercapai terhadap pembelajaran bagi anak tunagrahita sedang.

Dari uraian di atas banyak masalah yang dihadapi bagi pembelajaran untuk anak tunagrahita sedang oleh seoarang guru sebagai ujung tombak dalam dunia pendidikan. Pada kesempatan ini penulis sebagai seorang guru di Sekolah Luar Biasa mencoba untuk mengatasi salah satu permasalahan dalam pembelajaran berhitung dengan melakukan penelitian tentang yakni: Penggunaan Media Permainan Karambol dalam Meningkatkan Hasil Belajar Berhitung Pada Anak Tunagrahita Sedang.

Proses pembelajaran pada intinya adalah pemberian layanan kepada setiap individu siswa agar mereka berkembang secara maksimal sesuai dengan potensi yang mereka miliki (Depdiknas,2002). Menelaah pengertian proses pembelajaran yang dikemukakan tersebut telah sejalan dengan paradigma baru dalam proses pembelajaran, yakni harus berpusat pada siswa. Dengan demikian segala tindakan yang dilakukan dan berbagai kriteria yang ditentukan merupakan hasil pertimbangan terhadap siswa yang dilayani. Oleh karena itu guru harus mengenal murid yang sedang mereka ajar. Selain itu, guru harus mengetahui bagaimana mengajar secara menarik ( Anggraena, 2008)

Manfaat penggunaaan alat peraga bagi anak tuagrahita yaitu untuk menarik minat anak belajar agar tidak cepat bosan karena anak tunagrahita cepat sekali bosan dalam menerima pelajaran, mencegah verbalisme yaitu anak hanya tahu kata-kata tanpa mengerti maksudnya anak tunagrahita sering menirukan apa yang didengar atau dikatakan oleh temannya padahal mereka tidak tahu maksud yang dikatakan tersebut, dengan alat peraga pengalaman anak akan diberikan secara baik yaitu dari yang paling konkrit menuju ke hal yang semi konkrit akhirnya ke hal-hal yang abstrak. Dengan demikian proses proses pembelajaran bagi anak tunagrahita harus dikemas sedemikian rupa sehingga siswa yang memiliki kecerdasan rendah, motivasi belajar rendah dan prilaku yang kekanak-kanakan walaupun usianya telah dewasa tetap terdorong dan mau mengikuti pembelajaran dengan cara bermain yang sekiranya disenangi anak, mudah dalam memainkannya dan ada tantangan yang tarafnya sederhanan sesuai dengan potensi anak tunagrahita. Dengan permainan karambol yang sudah sangat memasyarakat dan tidak asing bagi semua orang, tentu anak tunagrahita akan tertarik untuk bermain karambol yang sebenarnya dapat digunakan sebagai media dalam proses pembelajaran. Diharapkan siswa tunagrahita dengan tidak menyadari sedang bermain sambil belajar, mereka akan asyik dan merasa senang mengikuti pelajaran berhitung misalnya, sehingga dengan perasaan senang mereka akan bertahan lama dalam kegiatan belajar.

Mengingat banyaknya permasalah yang dihadapi dalam pembelajaran bagi anak tunagrahita sedang sebagaimana yang digambarkan di atas penulis mencoba mencari solusi untuk memperlancar proses pembelajaran, yakni dengan menggunakan alat peraga permainan yang sederhana, murah, mudah, praktis dan menarik yang diharapkan efektif untuk membantu memperlancar proses pembelajaran bagi anak tunagrahita sedang. Untuk lebih jelasnya rumusan masalah yang akan diteliti dalam Penelitian ini: (a)Apakah media permainan karambol dapat dalam meningkatkan hasil belajar dalam proses pembelajaran berhitung bagi anak tunagrahita sedang? (b)Apakah penggunaan media permainan karambol dalam proses belajar berhitung bagi anak tunagrahita sedang dapat menumbuhkan perhatian, minat dan rasa senang dalam proses pembelajaran?

Sesuai dengan permasalahan penelitian yang telah dikemukakan di atas maka Penelitian Tindakan Kelas ini bertujuan sebagai berikut: (a)Untuk mengetahui ada tidaknya penggunaan 
media permaianan karambol dalam meningkatkan hasil belajar bagi anak tunagrahita sedang. (b)Untuk mengetahui berpengaruh atau tidaknya penggunaan media permainan karambol untuk kelancaran proses belajar berhitung bagi anak tunagrahita sedang.(c)Untuk mengetahui dapat tidaknya media permainan karambol menumbuhkan perhatian, minat dan rasa senang bagi anak tunagrahita sedang dalam proses pembelajaran berhitung.

Diharapkan dengan adanya media karambol dapat menjadi salah satu media pembelajaran dalam pelajaran berhitung bagi anak tunagrahita.

Diharapkan dengan adanya media karambol dapat menjadi salah satu media pembelajaran dalam pelajaran berhitung bagi anak tunagrahita.

\section{METODE PENELITIAN}

Metode penelitian yang akan dilaksanakan adalah penelitian tindakan kelas ini penulis memilih metode deskriftif kualitatif yaitu suatu metode yang digunakan guru untuk memecahkan permasalahan pembelajaran yang terjadi dalam praktek mengajar sehari-hari untuk menuju situasi dan kondisi pembelajaran yang kondusif, melalui tindakan yang terencana dan terlaksana dengan beberapa tahapan dalam penelitian tindakan kelas ini.

Subyek penelitian tindakan kelas ini peneliti mengambil siswa kelas 6 SDLB tunagrahita sedang SPLB C YPLB Cipaganti Kota Bandung yang berjumlah 4 orang siswa. Adapun waktu penelitian dilakukan pada semester II tahun ajaran 2017-2018. Lokasi penelitian ini di kelas 6 SDLB bertempat di SPLB C YPLB Cipaganti Kota Bandung Provinsi Jawa Barat.

Prosedur penelitian sebagai alat untuk mengumpulkan data yang diteliti pada penelitian ini menggunakan III siklus dengan gambaran umum pada setiap siklusnya adalah sebagai berikut:

1. Perencanaan

2. Pelaksanaan Tindakan Pembelajaran

3. Observasi

4. Refleksi

Teknik untuk mengumpulkan data pada penelitian ini diambil dari tes hasil belajar yang mengukur apa yang telah dipelajari pada berbagai bidang studi, jenis data yang dapat diambil menggunakan hasil belajar ini adalah taraf prestasi dalam belajar. Instrumen test yang digunakan adalah dengan menceklist hasil belajar siswa oleh guru dan lembar observasi ini merupakan instrumen untuk mencatat data-data yang diteliti sesuai dengan kejadian pada saat proses pembelajaran berlangsung. Pada lembar observasi ini berisi tentang pernyataanpernyataan yang sesuai dengan indikator-indikator penelitian sebagaimana tertuang dalam kisikisi instrumen penelitian.

Untuk memperoleh data-data yang diperlukan menggunakan teknik-teknik sebagai berikut:

a.Studi Kepustakaan, yaitu untuk memperoleh keterangan-keterangan ilmiah dari buku sumber, karangan ilmiah, laporan penelitian tindakan kelas dan internet yang berkaitan dengan masalah yang diteliti

b.Observasi/pengamatan, yaitu suatu teknik pengumpulan data dengan menggunakan pedoman observasi yang berisi tentang permasalahan yang diteliti yaitu pengaruh penggunaan media permainan karambol dalam proses pembelajaran berhitung.

\section{HASIL DAN PEMBAHASAN}

\section{Gambaran penelitian}

Media pembelajaran dalam kegiatan belajar sangat diperlukan untuk menunjang kemampuan siswa dalam memahami suatu pelajaran tidak terkecuali bagi anak tunagrahita. Anak tunagrahita sedang sangat memperlukan media dalam kegiatan pembelajaran untuk menjelaskan hal-hal yang abstrak kedalam bentuk yang lebih konkrit karena anak tunagrahita sedang sulit untuk memahami hal-hal yang abstrak Masih adanya sekolah yang belum menggunakan media pembelajaran mencerminkan belum tumbuhnya kreativitas yang tinggi dari para guru untuk dapat dan mau membuat atau menyediakan media pembelajaran sendiri. 
Sebagai akibat dari minimnya media pembelajaran yang digunakan dalam proses belajar mengajar, maka dampaknya terhadap siswa yang sedang belajar menjadi kurang begitu semangat, cepat bosan, tidak menarik minat siswa dan pada akhirnya mengakibatkan rendahnya tarap daya serap siswa terhadap materi pelajaran. Berangkat dari permasalahan tersebut diatas penulis mencoba untuk mengatasi salah satu permasalahan dalam proses pembelajaran yang dilakukan seadanya.

Salah satu upaya yang dilakukan penulis untuk meningkatkan semangat belajar siswa dengan memodifikasi permaianan karambol menjadi suatu medai pembelajaran berhitung dalam proses belajar mengajar. Media ini dimaksudkan untuk mendorong dan memperbaiki hal-hal sebagai berikut:

1. Meningkatkan minat dan semangat belajar siswa.

2. Mendorong siswa untuk lebih aktif dalam proses pembelajaran

3. Membuat siswa mau dan mampu untuk belajar dalam waktu yang relatif lama

4. Menciptakan suasana belajar yang menyenangkan sehingga diharapkan konsentrasi siswa dalam pores pembelajaran menjadi lebih baik

5. Memudahkan siswa untuk mengetahui dan menyerap materi pelajaran

6. Memudahkan guru dalam memfasilitasi siswa untuk dapat mengikuti pembelajaran dengan baik

7. Meningkatkan efektivitas, efisiensi dan fleksibilitas dalam mengolah pembelajaran Upaya tersebut di atas dilakukan mengingat kondisi anak tunagrahita dalam hal ini anak tunagrahita sedang kelas VI SDLB-C yang terdiri dari 4 orang banyak mengalami hambatan dalam kegiatan belajar berhitung. Sehingga diperlukan media pembelajaran yang menunjang dalam kegiatan belajarannya. Oleh karena itu dalam kegiatan pembelajarannya anak tunagrahita sedang memerlukan pelayanan secara optimal.

\section{Uraian Penelitian Secara Umum}

Untuk mengetahui keadaan permasalahan yang diteliti yaitu tentang pengaruh penggunaan media permaianan karambol untuk mendorong dan menunjang kelancaran dalam kegiatan pembelajaran, tumbuhnya minat dan perasaan senang dari siswa dalam mengikuti kegiatan pembelajaran serta tingkat kegunaan media permainan karambol dalam belajar berhitung bagi siswa tunagrahita sedang, dilakukan dengan tes belajar yang diisi saat proses belajar mengajar berlangsung dengan cara menceklist hasil belajar siswa oleh guru dengan dua kemungkinan jawaban dan dengan pengukuran menggunakan lembar observasi/pengamatan yang diisi saat proses pembelajaran berlangsung sebagai refleksi dari sikap belajar siswa. Setiap pernyataan masing-masing disertai dengan lima kemungkinan jawaban untuk dipilih yang dipandang paling sesuai dengan keberadaan siswa saat mengikuti proses pembelajaran.

Tiap-tiap siswa memiliki data dari hasil proses pembelajaran yang diikutinya yang berhubungan dengan pokok permasahan yang diteliti. Data hasil yang diperoleh tiap siswa tentunya relatif berbeda sesuai dengan karakteristik individunya masing-masing yang terealisasi dalam keaktifannya sewaktu mengikuti proses pembelajaran.

\section{Penjelasan Siklus Pembelajaran}

Secara umum gambaran yang ada pada setiap siklus adalah sebagai berikut:

a. Siklus I

Pada siklus 1 ini akan menampilkan belajar berhitung dengan permainan karambol menggunakan biji karambol yang bertuliskan angka 1-5 sebanyak 20 biji karambol dan 1 biji karambol penembak (kokojo)

Kegiatan yang akan dilakukan meliputi:

1. Perencanaan

Perencanaan pembelajaran sangat penting untuk tercapainya tujuan pembelajaran. Berikut perencanaan pembelajaran pada siklus I :

a. Menyusun RPP 
b. Menyiapkan media karambol

c. Menyusun dan menyiapkan instrumen penelitian seperti: lembar tes siswa dan lembar observasi kegiatan siswa.

2. Pelaksanaan Tindakan Pembelajaran

Pelaksanaan tindakan dilaksanakan dengan langkah-langkah kegiatan awal, kegiatan inti dan kegiatan penutup.

a. Kegiatan pendahuluan diawali dengan guru mengkondisikan siswa dalam situasi belajar, menanyakan kabar, memberi motivasi. Kemudian guru bersama siswa berdoa sebelum belajar dilanjutkan dengan mengabsen siswa. Melakukan apersepsi dengan menanyakan sejauh mana pengetahuan siswa tentang berhitung.

b. Pada kegiatan inti guru menjelaskan cara bermain karambol dalam proses belajar berhitung dengan memasukan biji karambol ke lubang meja dengan cara menyentikan jari ke biji karambol (kokojo) dengan sasaran biji karambol lainnya yang bertuliskan angka diarahkan ke lubang meja karambol yang ada disetiap sudut meja. Kemudian siswa menyebutkan angka biji karambol yang masuk dalam lubang meja karambol, kemudian siswa mengambil biji karambol yang lainnya sesuai dengan angka yang tertera pada biji karambol. Siswa belajar dengan didampingi oleh guru dalam hal ini peneliti

c. Pada kegiatan penutup guru memberi kesempatan bertanya pada siswa seputar permainan karambol. Kemudian guru bersama dengan siswa menyimpulkan materi pembelajaran yang telah dipelajari.

3. Observasi

Dalam kegiatan observasi ini peneliti di damping juga oleh seorang observer untuk mengamati, mendokumentasikan aktivitas dan respon siswa selama pelaksanana kegiatan pembelajaran berlangsung. Observasi ini dilakukan sebagai pengumpulan data selama penelitian berlangsung

4. Refleksi

Dalam kegiatan refleksi ini untuk mengetahui apa saja yang telah dicapai dan yang belum dicapai dalam pelaksanan kegiatan pada setiap siklusnya serta membahas tindakan yang akan dilakukan pada siklus berikutnya.

b.Siklus II

Pada siklus II ini akan menampilkan belajar berhitung dengan permainan karambol menggunakan biji karambol yang bertuliskan angka 6 -10 sebanyak 20 biji karambol dan 1 biji karambol penembak (kokojo). Kegiatan yang dilakukan sama seperti pada siklus I yaitu: perencanaan, pelaksanaan tindakan pembelajaran, observasi dan refleksi c.Siklus III

Proses yang dilakukan dalam siklus III ini sama dengan proses pembelajaran pada siklus kedua hanya materi pembelajarannya yang berbeda Pada kedua siklus sudah mengenal permaian karambol untuk belajar berhitung angka 1-5 pada siklus pertama dan angka 6-10 pada siklus kedua, maka pada siklus III ini siswa bermain karambol dengan menggunakan biji karambol dari angka 1 - 10 sebanyak 20 biji karambol dan 1 biji karambol sebagai penembak (kokojo).

\section{Hasil Penelitian}

Setelah pelaksanaan perbaikan pembelajaran pada siswa kelas VI SDLB Tunagrahita Sedang SPLB C YPLB Cipaganti Kota Bandung Provinsi Jawa Barat melalui PenelitianTindakan Kelas dengan menggunakan tiga siklus secara keseluruhan proses berhitung melalui media permainan karambol dikatakan berhasil karena mengalami peningkatan dalam setiap siklusnya. Untuk lebih jelasnya peningkatan hasil belajar dan hasil observasi terdapat pada tabel berikut: 
Tabel 1. Hasil Tes Awal dan Siklus I, II, III

\begin{tabular}{|l|l|l|l|l|l|}
\hline \multirow{2}{*}{ No } & \multirow{2}{*}{ Kode Siswa } & NILAI & Siklus I & Siklus II & Siklus III \\
\cline { 3 - 6 } & & Kondisi Awal & 6 & 6 & 7 \\
\hline 1. & LL & 5 & 6 & 5 & 6 \\
\hline 2. & AJ & 3 & 5 & 6 & 6 \\
\hline 3. & RS & 4 & 6 & 7 & 8 \\
\hline 4. & AH & 6 & 22 & 24 & 27 \\
\hline Jumlah & 18 & 5,50 & 6,00 & 6,75 \\
\hline Rata-rata & 4,50 & 2 & 1 & 0 \\
\hline Belum tuntas & 3 & $50 \%$ & $25 \%$ & 0 \\
\hline Prosentasi belum tuntas & $75 \%$ & $50 \%$ & $75 \%$ & $100 \%$ \\
\hline Prosentasi tuntas & $25 \%$ & & & \\
\hline
\end{tabular}

Berdasarkan data diatas, menunjukkan hasil perolehan nilai mengalami peningkatan. Hasil ini dapat di lihat dari rata-rata kelas dan presentasi ketuntasan yang meningkat. Walaupun pada setiap evaluasi siswa tetap dibimbing dalam mengerjakan tugas yang diberikan.

Perkembangan hasil belajar siswa melalui perbaikan pembelajaran berhitung dengan menggunakan permaianan karambol pada kompetensi dasar meletakkan benda sesuai dengan lambang bilangan dapat dilihat pada grafik. Terlihat dari grafik di bawah ini dalam setiap siklusnya mengalami peningkatan. Pada siklus pertama dengan media permainan karambol dapat meningkatkan rata-rata belajar dari kondisi awal ke siklus pertama ada peningkatan 1 dari rata-rata 4,50 menjadi 5,50. Pada siklus kedua ada peningkatan 0,5 dari rata-rata hasil belajar siswa 5,50 menjadi 6,00 dan pada siklus ketiga rata-rata hasil belajar naik 0,75 dari 6,00 menjadi 6,75. Dari hasil belajar siswa dengan menggunakan media permainan karambol ada peningkatan hasil belajar berhitung dengan kompetensi dasar meletakkan benda sesuai dengan lambang bilangannya.

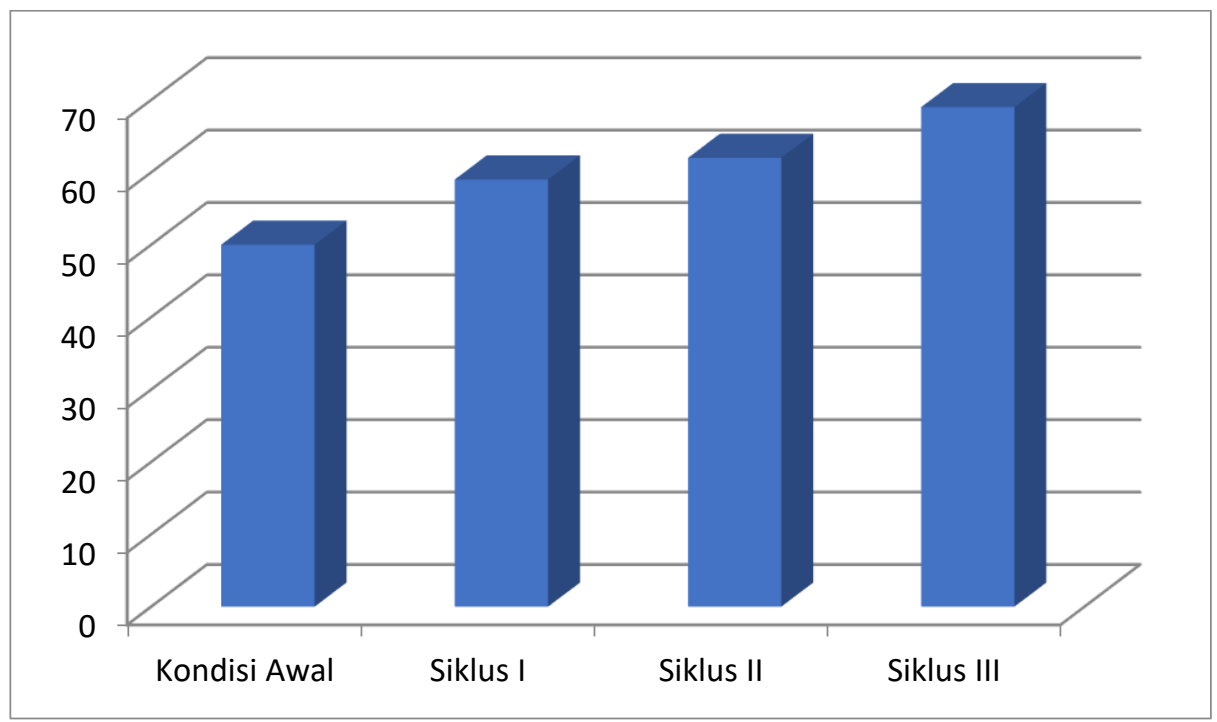

Gambar 2. Grafik hasil belajar

\section{Pembahasan}

Penelitian tindakan kelas adalah penelitian praktis yang dimaksudkan memperbaiki pembelajaran dikelas (Kasbolah, 1999) Hopkin (Indrawati dan Widjaya, 2001) mengartikan bahwa : Penelitian tindakan kelas yang dilakukan oleh guru untuk meningkatkan dirinya atau teman sejawatnya untuk menguji asumsi-asumsi teori pendidikan di dalam praktek atau mempunyai makna sebagai evaluasi dan implementasi keseluruhan prioritas sekolah. Penelitian tindakan kelas ini dilaksanakan di kelas 6 SDLB SPLB C YPLB Cipaganti Kota Bandung. Penelitian ini bertujuan untuk mengetahui penggunaan permainan karambol untuk 
meningkatkan hasil belajar berhitung pada anak tunagrahita sedang pada semester genap tahun pelajaran 2017-2018. Penelitian ini dilatarbelakangi dari belum mampunya siswa memahami konsep berhitung dan rendahnya nilai ulangan siswa. Hal ini bisa disebabkan dalam kegiatan pembelajaran guru tidak menggunakan media pembelajaran, padahal media pembelajaran sangat bermanfaat dalam proses pembelajaran yang dapat memotivasi siswa untuk aktif dalam proses belajar, menimbulkan rasa senang dan konsep berhitung tersajikan dalam bentuk konkret sehingga lebih mudah dimengerti dan dipahami (Ruseffendi 1990)

Berdasarkan permasalahan tersebut, peneliti mencoba mencari solusi untuk memecahkan permasalahannya diantaranya dengan menggunakan media permainan karambol dalam pembelajaran karena dengan adanya konteks bermain dalam belajar disertai media yang tepat dapat membantu meningkatkan kemampuan dan minat peserta didik dalam melakukan pembelajaran (Qurrotul, 2015). Media permainan karambol dipilih karena dapat meningkatkan keberhasilan hasil belajar peserta didik dan juga meningkatkan keaktifan peserta didik dalam kegiatan pembelajaran (Jahidin, 2008)

\section{KESIMPULAN}

Berdasarkan hasil tes awal dari data yang didapat menunjukkan hasil yang tidak begitu baik dan siswa kurang begitu termotivasi dan konsentrasi untuk belajar berhitung. Pada siklus I dan II sudah ada peningkatan dalam minat dan perhatian siswa untuk belajar berhitung terlihat dari hasil belajar yang juga mengalami peningkatan. Pada siklus III lebih banyak lagi peningkatan yang ditunjukkan siswa dalam proses pembelajaran terlihat dari hasil belajar siswa. Hal ini menunjukkan bahwa penggunaan media permainan karambol dapat meningkatkan hasil belajar peserta didik dan dapat meningkatkan peran aktif dan konsentrasi peserta didik serta dapat menarik minat dan perhatian peserta didik untuk mengikuti kegiatan pembelajaran dengan suasana senang dan nyaman, sehingga memudahkan peserta didik untuk mengerti dan memahami materi pelajaran serta diharapkan mendapatkan hasil belajar yang baik.

\section{DAFTAR PUSTAKA}

Abdul Majid (2008). Perencanaan Pembelajaran. Bandung: PT Remaja Rosdakarya

Arikunto, Suharsimi, dkk (2006). Penelitian Tindakan Kelas. Jakarta: Bumi Aksara

Astati(1990). Ortopedagogik C1. Bandung : Jurusuan Pendidikan Luar Biasa FIP IKIP Bandung (Diktat)

Jahidin (2008). Efektifitas penggunaan alat peraga karambol dalam pembelajaran membaca permulaan bagi siswa tunagrahita ringan kelas dasar di SLB-ABC Muhamamadiyah Banjarsari kabupaten Ciamis PTK diakses dari academia.edu

Qurrotul A. (2015) Pengaruh penggunaan media Dot Karambol Terhadap Kemampuan Operasi Hitung Penjumlahan Peserta Didik Tunagrahita. Jurnal Penelitian dan Pengembangan Pendidikan Luar Biasa

Ruseffendi E.T. (1979). Pengajaran Matematika untuk Orang Tua Murid, Guru dan SPG (seri II, IV). Bandung: Tarsito

Yani Meimulyani, Caryoto.(2013). Media Pembelajaran Adaptif. Luxima Metro Media 